Acta vet. scand. $1978,19,354-367$.

From the Department of Obstetrics and Gynaecology and the Ambulatory Clinic, Hautjärvi, and the Department of Animal Hygiene, Helsinki, College of Veterinary Medicine, Finland.

\title{
INCIDENCE OF INFERTILITY IN DAIRY COWS
}

\author{
By \\ K. Roine and H. Saloniemi
}

ROINE, K. and H. SALONIEMI: Incidence of infertility in dairy cows. Acta vet. scand. 1978, 19, 354-367. - The incidence of anoestrus, suboestrus, delayed ovulation, cystic ovaries, repeat breeder cows, endometritis and other forms of infertility was studied in 283 herds over a period of eight years $(2,304$ cases $)$. The total incidence of infertility ( 0.111 cases per cow per year) varied significantly from year to year. The peak of the seasonal variation occurred in DecemberApril and did not correspond with the seasonal variation in calving. Both the size of herd and the type of housing affected the incidence of infertility, but the differences were great in respect of the various diagnoses. The incidence of ketosis by herd correlated significantly with the incidence of infertility by herd.

disease incidence; infertility; herd size;

housing type; dairy cows.

The economic importance of infertility in cows has been emphasized in recent years. It has been found necessary to study not only the treatment of infertility but also the occurrence of fertility disorders and factors affecting the occurrence. Studies of the incidence of infertility have been infrequent, for instance because of the lack of sufficiently detailed and reliable systems of disease statistics.

'The most extensive studies on the incidence of infertility have been carried out in Scandinavia. The occurrence of reproductive disorders was studied, for example, by Bane (1964) and Bäckström et al. (1975). An extensive analysis of the effects of various environmental factors on the fertility of dairy cows was conducted in Sweden by Hewett (1971). Individual disorders of reproduction that have been studied involve the incidence of cystic ovaries (Henricson 1956, Pålsson 1961, Schjerven 1971), and the incidence of repeat breeder cows (Hewett 1968, de Kruif 
1975). In Finland material gathered in the district of the ambulatory clinic of the College of Veterinary Medicine has been published about the incidence of reproductive disorders (Moberg 1965, Roine 1973, Roine 1975), about the total incidence of sterility (Saloniemi \& Roine 1976) and about the incidence of genital abnormalities as based on slaughterhouse material (Roine 1977).

The present study will examine the incidence of infertility of the cow population of a restricted area. Particular attention will be devoted to the incidence of infertility from year to year, to seasonal variation, and to the effect of the size of herd on the incidence of infertility. The study is a part of the above analyses of infertility in cows and the incidence thereof, conducted at the College of Veterinary Medicine. Further studies will be made in an endeavour to analyse the effects of various forms of infertility on fertility and thus to assess the economic impact of such diseases on cattle husbandry. Our studies with this objective have been in progress at 32 cattle farms since the beginning of 1977 , based on a previously described plan (Saloniemi 1976).

\section{MATERIAL AND METHODS}

The material comprises the infertility cases of 283 herds within the district of the ambulatory clinic in 1968-1975 which were treated by a clinic veterinarian and recorded on farm cards (Roine 1969). Repeated treatment of any single cow was not recorded as a new case. If the treatment was followed by normal oestrus and insemination, but disorders were thereafter diagnosed again, the case was recorded as a new one. Most of the diagnoses are based on a single clinical examination, and in somes cases they are obviously probability diagnoses. Difference may also have occurred, of course, among the diagnoses of the different veterinarians of the clinic. An attempt was made to reduce such differences by employing the following definitions of various types of infertility.

A n o e s t r u s: no external signs of oestrus found, and rectal examination revealed inactive ovaries without large follicles or corpus luteum.

$\mathrm{S}$ u b o e $\mathrm{s}$ t r u s: no clear external signs of oestrus, or a slight metoestral bleeding observed. Rectally, a follicle or follicles and corpus luteum found.

Delayed ovulation: the oestrus lasted for above 48 
hrs., the occurrence of ovulation was not observed in repeated examinations.

Cystic ovaries: in one or both ovaries one or more cysts larger than a normal follicle (above $2 \mathrm{~cm}$ ) were found.

Repeat breeder cow: normal oestrus and regular cycle but not pregnant after two inseminations.

Endometritis: continuing or above normal flow of secretion from the uterus. Acute puerperal metritis not included.

Other forms of infertility: apart from the above, there are such cases as probable early embryonic death, bursal adhesions, corpus luteum cysts, malformations, etc.

The distribution of the material into the diagnoses defined above is presented in Table 1. The same Table shows the various diagnoses as percentages of all the diseases (11,443 cases) treated by veterinarian during the period.

Table 1. Total number of different types of infertility and their percentual part of all diseases.

\begin{tabular}{lccc}
\hline Disease & $\begin{array}{c}\text { Number of } \\
\text { cases }\end{array}$ & $\begin{array}{c}\% \text { of } \\
\text { infertility }\end{array}$ & $\begin{array}{c}\text { \% of all } \\
\text { diseases }\end{array}$ \\
\hline Anoestrus & 312 & 13.5 & 2.7 \\
Suboestrus & 481 & 20.9 & 4.2 \\
Delayed ovulation & 128 & 5.6 & 1.1 \\
Cystic ovaries & 855 & 37.1 & 7.5 \\
Repeat breeder cows & 190 & 8.2 & 1.7 \\
Endometritis & 293 & 12.7 & 2.6 \\
Other infertility types & 45 & 2.0 & 0.4 \\
\hline Total & 2,304 & 100.0 & 20.1 \\
\hline
\end{tabular}

The farm cards supplied the diagnosis, the year, month, size of herd in number of cows, type of housing and stalls, and participation in milk recording. The information was entered on punch cards for each farm, and the information was processed at the Agricultural Data Processing Centre by ordinary statistical methods. The incidence of all diseases, i.e. the number of cases per cow per year, was calculated for each herd for each examined year. The incidences for the various groups according to herd size and for the types of housing, as also for the milk recording farms, were calculated and the effects of variables were estimated by one way analysis of variance. The effects of herd size and type of housing were also estimated by method of least squares (Har- 
vey 1966). The linear correlation coefficients between the variables were also calculated. Correlations were confirmed by Chi-square test of independence. The annual and monthly variations were calculated in respect of numbers of cases, and the tests were made by Chi-square method. To compare the seasonal variation of incidences with the seasonal variation in calving, the data on calving were extracted from the calving information of the milk recording herds in the district of the Uusimaa Agricultural Centre for 1967-1975 (some 12,000 cows per year), from which the monthly averages were calculated (Table 4 ).

The cows covered by the data (2,590 cows per year in average) were $90 \%$ of the Finnish Ayrshire breed. Most of the others were cross-breds and a minor proportion of the Finncattle and the Friesian breeds.

\section{RESULTS}

The averages per herd for the incidence of infertility, and the average incidence, are shown in Table 2 . The infertility incidence was 0.111 cases per cow per year. The variations among farms were marked.

Table 2. Total incidence of infertility types and incidence counted on herd basis.

\begin{tabular}{lcc}
\hline Disease & $\begin{array}{c}\text { Total } \\
\text { incidence }\end{array}$ & $\begin{array}{c}\text { Incidence on herd } \\
\text { basis }\end{array}$ \\
\hline Anoestrus & 0.015 & 0.013 \\
Suboestrus & 0.023 & 0.021 \\
Delayed ovulation & 0.006 & 0.006 \\
Cystic ovaries & 0.041 & 0.039 \\
Repeat breeder cows & 0.009 & 0.009 \\
Endometritis & 0.014 & 0.011 \\
Other infertility types & 0.002 & 0.002 \\
\hline Total & 0.111 & 0.101 \\
\hline
\end{tabular}

The incidence of infertility in different years is shown in Table 3. The annual variations are statistically significant for anoestrus, suboestrus, delayed ovulation and cystic ovaries. The total infertility likewise varies significantly from year to year.

The monthly variation in infertility is shown in Table 4 . Monthly distribution of cystic ovaries observed and theoretically 
T a b l e 3. Annual distribution of infertility types and significance test for variation of incidence between years.

\begin{tabular}{lrrrrrrrr}
\hline Year & Anoestrus & $\begin{array}{c}\text { Sub- } \\
\text { oestrus }\end{array}$ & $\begin{array}{c}\text { Delayed } \\
\text { ovulation }\end{array}$ & $\begin{array}{c}\text { Cystic } \\
\text { ovaries }\end{array}$ & $\begin{array}{c}\text { Repeat } \\
\text { breeder } \\
\text { cows }\end{array}$ & $\begin{array}{c}\text { Endo- } \\
\text { metritis }\end{array}$ & $\begin{array}{c}\text { Other infer- } \\
\text { tility types }\end{array}$ & Total \\
\hline 1968 & 51 & 50 & 37 & 116 & 23 & 33 & 7 & 317 \\
1969 & 47 & 39 & 22 & 101 & 24 & 45 & 6 & 284 \\
1970 & 27 & 41 & 18 & 125 & 22 & 25 & 1 & 259 \\
1971 & 27 & 57 & 15 & 117 & 35 & 31 & 5 & 287 \\
1972 & 26 & 84 & 10 & 120 & 22 & 37 & 6 & 305 \\
1973 & 53 & 89 & 6 & 101 & 27 & 37 & 4 & 317 \\
1974 & 38 & 46 & 4 & 99 & 18 & 40 & 1 & 246 \\
1975 & 43 & 75 & 16 & 76 & 19 & 45 & 15 & 289 \\
\hline T'otal & 312 & 481 & 128 & 855 & 190 & 293 & 45 & 2,304 \\
Mean & 39.0 & 60.1 & 16.0 & 106.9 & 23.8 & 36.6 & 5.6 & 288.0 \\
$\chi^{2}$ & 22.5 & 45.8 & 47.6 & 16.55 & 8.3 & 9.0 & - & 15.95 \\
d.f. & 7 & 7 & 7 & 7 & 7 & 7 & & 7 \\
P & $<0.01$ & $<0.001$ & $<0.001$ & $<0.05$ & $>0.05$ & $>0.05$ & & $<0.05$ \\
\hline
\end{tabular}

calculated distribution of cystic ovaries based on distribution of calvings are shown in Figure 1. As the great seasonal variation in calving naturally has an effect on the number of fertility disorders in the different months, a comparison between monthly distributions was made by Chi-square test. In the distribution of delayed ovulation the months VI-VII and VIII-IX were combined, and in that of repeat breeder cows the months VI-VII were combined, in order to obtain a large enough $(>10)$ expected value. However, the seasonal variation did differ from the seasonal variation in calving by the $0.1 \%$ risk in respect of the incidences of anoestrus, suboestrus, cystic ovaries and total infertility; by a risk of $1 \%$ in respect of delayed ovulation; and by a risk of $5 \%$ where repeat breeder cows and endometritis are concerned. As many of the infertility cases come under veterinary care about three months after calving, the distributions were also compared with the relative distribution of those cows that had calved three months earlier. The difference between the distributions increased in all cases.

When the material was divided into groups on the basis of size of herd it was found that the incidence of infertility was more common in the large herds (Table 5). The incidences of anoestrus, suboestrus, delayed ovulation, cystic ovaries and endometritis were significantly different among the various sizes of 
T a b l e 4. Monthly distribution of infertility types, distribution of calvings and Chi-square test between monthly distribution and distribution of calving.

\begin{tabular}{lrrrrrrrrr}
\hline Month & Anoestrus & $\begin{array}{c}\text { Sub- } \\
\text { oestrus }\end{array}$ & $\begin{array}{c}\text { Delayed } \\
\text { ovulation }\end{array}$ & $\begin{array}{c}\text { Cystic } \\
\text { ovaries }\end{array}$ & $\begin{array}{c}\text { Repeat } \\
\text { breeder } \\
\text { cows }\end{array}$ & $\begin{array}{c}\text { Endo- } \begin{array}{c}\text { Other fer- } \\
\text { metritis tility types }\end{array} \\
\text { Total }\end{array}$ & $\begin{array}{c}\text { Distribu- } \\
\text { tion of } \\
\text { calvings } \\
\%\end{array}$ \\
\hline I & 43 & 55 & 18 & 105 & 14 & 28 & 6 & 269 & 8.74 \\
II & 50 & 78 & 16 & 101 & 21 & 29 & 5 & 299 & 8.05 \\
III & 57 & 84 & 22 & 101 & 31 & 46 & 6 & 347 & 12.54 \\
IV & 64 & 69 & 13 & 57 & 20 & 39 & 5 & 267 & 13.70 \\
V & 25 & 29 & 8 & 48 & 12 & 39 & 7 & 168 & 9.10 \\
VI & 9 & 17 & 8 & 52 & 6 & 10 & 2 & 104 & 4.38 \\
VII & 7 & 22 & 10 & 70 & 24 & 12 & 4 & 149 & 4.70 \\
VIII & 9 & 14 & 6 & 61 & 13 & 8 & 4 & 115 & 6.68 \\
IX & 2 & 20 & 10 & 38 & 15 & 13 & 1 & 99 & 7.17 \\
X & 5 & 13 & 5 & 52 & 10 & 21 & 3 & 109 & 8.55 \\
XI & 15 & 33 & 6 & 69 & 9 & 18 & 1 & 150 & 7.96 \\
XII & 26 & 47 & 6 & 101 & 16 & 30 & 2 & 228 & 8.43 \\
\hline Total & 312 & 481 & 128 & 855 & 190 & 293 & 45 & 2,304 & 100.0 \\
$\chi^{2}$ & 105 & 95.6 & 22.6 & 126 & 23.1 & 23.6 & - & 226 & 11 \\
d.f. & 11 & 11 & 9 & 11 & 10 & 11 & & & \\
P & $<0.001$ & $<0.001$ & $<0.01$ & $<0.001$ & $<0.05$ & $<0.05$ & & 0.001 & \\
\hline
\end{tabular}

Table 5. Relationship between herd size and incidence of different infertility types.

\begin{tabular}{|c|c|c|c|c|c|c|c|c|c|}
\hline Herd size & $\begin{array}{l}\text { Number } \\
\text { of herds }\end{array}$ & Anoestrus & $\begin{array}{c}\text { Sub- } \\
\text { oestrus }\end{array}$ & $\begin{array}{l}\text { Delayed } \\
\text { ovulation }\end{array}$ & $\begin{array}{c}\text { Cystic } \\
\text { ovaries }\end{array}$ & $\begin{array}{c}\text { Repeat } \\
\text { breeder } \\
\text { cows }\end{array}$ & $\begin{array}{c}\text { Endo- } \\
\text { metritis }\end{array}$ & $\begin{array}{l}\text { Other infer- } \\
\text { tility types }\end{array}$ & Total \\
\hline $1-5$ & 68 & 0.008 & 0.015 & 0.003 & 0.027 & 0.009 & 0.008 & 0.000 & 0.071 \\
\hline $6-10$ & 132 & 0.013 & 0.022 & 0.008 & 0.046 & 0.010 & 0.009 & 0.002 & 0.108 \\
\hline $11-15$ & 53 & 0.013 & 0.020 & 0.005 & 0.033 & 0.006 & 0.013 & 0.002 & 0.091 \\
\hline $16-20$ & 17 & 0.018 & 0.026 & 0.010 & 0.045 & 0.008 & 0.023 & 0.003 & 0.133 \\
\hline $21-$ & 13 & 0.029 & 0.042 & 0.004 & 0.056 & 0.013 & 0.031 & 0.003 & 0.178 \\
\hline Mean & & 0.013 & 0.021 & 0.006 & 0.039 & 0.009 & 0.011 & 0.003 & 0.101 \\
\hline $\mathbf{F}$ & & 5.44 & 4.61 & 2.51 & 6.45 & 1.11 & 10.59 & 2.08 & 14.16 \\
\hline $\mathbf{P}$ & & $<0.01$ & $<0.01$ & $<0.05$ & $<0.01$ & $>0.05$ & $<0.01$ & $>0.05$ & $<0.01$ \\
\hline
\end{tabular}

herd as calculated by variance analysis. It was the incidences of anoestrus and endometritis that increased most distinctly with increasing size of herd $(r>0.10)$. Of the herds, 270 were in stalls with long standing, 11 in stalls with short standing and two in 


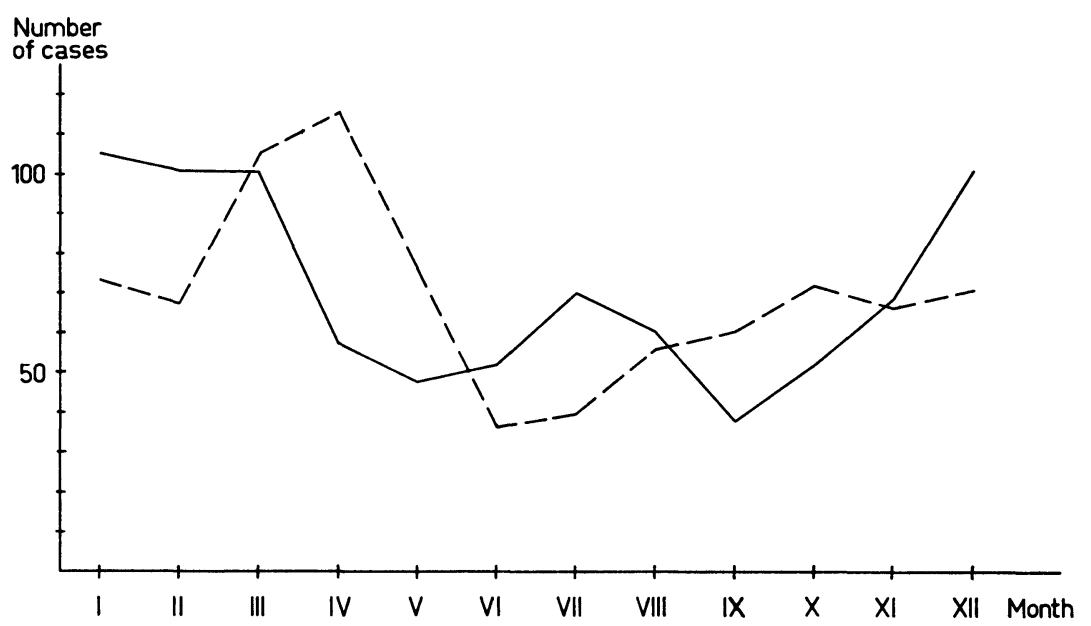

F i g u re 1. Monthly distribution of cystic ovaries observed (solid line) and theoretically calculated distribution of cystic ovaries based on distribution of calvings (dotted line).

littered loose housing. In 10 of the stalls with short standing the fodder included a large amount of silage. 'Ten of the cowsheds with short standing had a liquid manure system, while a straw manure system was used in other sheds. The incidences of anoestrus, suboestrus and endometritis, and the total incidence of infertility, were significantly higher in stalls with short standing $(P<0.01)$. As the herd size in the sheds with short standing averaged 19.8 cows, and in stalls with long standing only 8.7 , a least squares analysis of variance for these factors was calculated in order to establish any joint effects of size of herd and type of housing. The incidence of anoestrus seems to be significantly affected by the type of housing $(\mathrm{F}=8.51, \mathrm{P}<0.01)$ but not by the size of herd $(F=2.14, P>0.05)$. For suboestrus the result was similar; the type of housing seems to have an effect $(F=5.08, P<0.01)$ but the size of herd does not $(F=2.10$, $P>0.05)$. The incidence of endometritis is affected both by type of housing $(\mathrm{F}=8.64, \mathrm{P}<0.01)$ and by size of herd $(\mathrm{F}=6.07$, $P<0.01)$. In the same way, the total incidence of infertility is affected both by type of housing $(\mathrm{F}=6.46, \mathrm{P}<0.01)$ and by the size of herd $(\mathrm{F}=11.13, \mathrm{P}<0.01)$.

Eighty-nine of the studied farms participated in milk recording. The incidence of all different types of infertility was higher on these milk recording farms, the difference being statistically 
significant $(F>6.64, P<0.01)$ for all diseases except that of repeat breeder cows (Table 6).

A significant statistical relationship (Table 7) was established between the ketosis incidence and the incidence of infertility, by herd, especially in respect of suboestrus. When account was taken solely of the indoor feeding season (months VI-VIII omitted), the value of the correlation coefficient increased slightly in respect of the incidences of total infertility, anoestrus and endometritis, while it did not change for the other diseases. The inter-relationship between the incidences of infertility and ketosis was clearly greater during the last four years of the period studied. The correlation coefficients show that on farms where there was a great deal of infertility there is also an above average incidence of puerperal paresis $(\mathrm{r}=0.054, \mathrm{P}<0.01)$ and of mastitis $(r=0.098, P<0.001)$.

The correlations between the incidence in the various infertility types (Table 7) were related to disease incidences in the entire material solely in respect of anoestrus. The correlation coefficient between cystic ovaries and delayed ovulation incidence was greater than it was between cystic ovaries and repeat breeder cows incidence, although the average prevalence of the diseases in question was the reverse. With the incidence of endometritis there seems to be associated an above average incidence of anoestrus and a low incidence of repeat breeder cows.

Regarding the correlation coefficients for the incidence of other diseases and various forms of infertility, a mention should be made of the one between suboestrus and retained placenta $(\mathrm{r}=0.07, \mathrm{P}<0.001)$, between delayed ovulation and vaginal prolapse $(\mathrm{r}=0.06, \mathrm{P}<0.01)$.

\section{DISCUSSION}

On account of the extensiveness of the material and the length of the examined period, the result gives a good picture of the distribution of infertility which was treated by a veterinarian. The results do not indicate the absolute incidences of the diseases, for upon noticing the symptoms the cattle owner may opt for slaughter rather than calling in a veterinarian. Presumably this may be most common in the case of repeat breeder cows.

The distribution of various types of infertility (Table 1) matches the observations previously made in the same area 


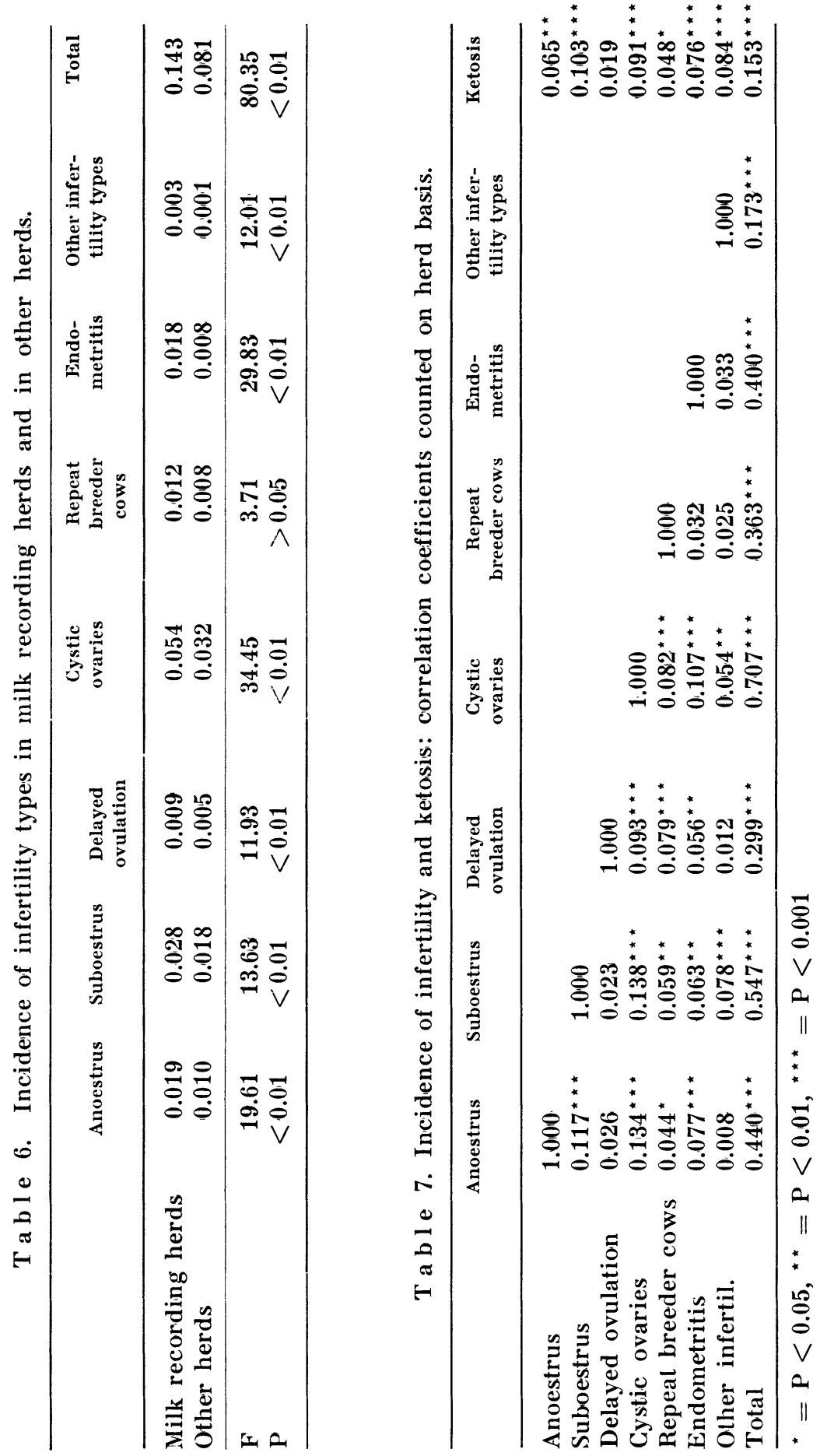


(Roine 1973, 1975). Anoestrus, suboestrus and cystic ovaries are the causes of some $70 \%$ of the treated infertility cases. There is very little infornation in the literature about the incidences of infertility; most frequently the fertility has been measured by various methods (e.g. Hewett 1971, de Kruif 1975). The combined incidence of anoestrus and suboestrus in the Swedish material of Bäckström et al. (1975) is only 0.016, and in the Norwegian study based on a large material (Solbu 1977) 0.010. These diseases represent about $1.9 \%$ in Sweden and $2.9 \%$ in Norway, of all the diseases, while the figure is 6.9 in the present study. We do not know of comparable results for incidence of delayed ovulation. Cystic ovaries are the form of infertility of which there has been most study. In Swedish studies the incidence has declined since the 1950's: Henricson (1956) 0.044, Pålsson (1961) 0.023, Bäckström et al. 0.003, the last figure being less than one tenth of the figure of 0.041 in the present study. Schjerven (1971) found that the incidence in Norway was 0.067 , and Solbu gives it as 0.017 . The incidence of repeat breeder cows in the material of Bäckström et al. was 0.003; Hewett (1968) gives the incidence as 0.101 , but the question is not one of cases treated by a veterinarian but of material assembled on the basis of data on insemination. The incidence of endometritis in the study by Rasbech et al. (1967) was 0.008, in that by Bäckström et al. 0.008 and in the present study 0.014 . The incidence of infertility in the present study was greater than that observed in the other Scandinavian countries.

The incidence of infertility in the present material varies significantly from year to year. Because of the extent of the material, the cause of the variation can be assumed to lie in environmental factors common to the farms, such as the weather conditions of the pasture season and the nutrional and hygienic qualities of the fodder. The possible effects of these factors on fertility have been discussed, for instance, by Hewett (1971) and Refsdal (1976). The results confirm the experience obtained in practice. Schjerven found no significant variation in the occurrence of cystic ovaries over a 10-year period; in the present study the variation was significant at a $5 \%$ level of risk.

Most of the cases of infertility are concentrated on the period December-April. The seasonal variation differs clearly from the variation due to calving: cows calving in the autumn have a higher incidence than cows that calve in spring. Both Hewett 
(1971) and de Kruif concur, in their fertility studies, that the fertility of cows calving in autumn is lower than that of cows calving in spring.

In the group containing anoestrus and suboestrus cases, the effect of dark indoor feeding season is very marked. The low number of these types of infertility recorded in the pasturing season is probably in part due to the stimulating of plant oestrogens on ovarian function (Kallela 1964). Cattle owners can also expect the pasturing season to cause improvement in any observed infertility symptom. Cases of repeat breeder cows occur more frequently among cows calving in September-February than among other cows, according to Hewett (1968). In the small material of the present study, repeat breeders are more common precisely three months after Hewett's time limit based on the date of calving.

Cases of cystic ovaries occur most frequently in DecemberMarch. The decrease in the number of cases towards the end of the indoor feeding season points at the significance of the lack of day light as an aetiological factor in conformity with the observations by Schjerven. The slight increase in this incidence found for July-August obviously derives from the effect of plant oestrogens (Kallela), from the seasonal variation in calving and from the higher age of cows calving in the spring; the age disposition is obvious also for cystic ovaries (Anttila \& Roine 1972). The interval between calving and diagnosis is two to three months (Anttila \& Roine), and the cows treated in December-March presumably calved in October-January. The observation differs from the report by Pålsson that there was a higher incidence of cystic ovaries in cows that calved in July-August.

There is very little information about the effect of size of herd on infertility where small herds are concerned. Hewett (1968) found that the incidence of repeat breeder cows increases significantly as soon as herds exceed five cows, and that the fertility decreases for herds over 14 cows (Hewett 1971). The increase in the total incidence of infertility with increasing size of herd, observed in the present study, contains interaction factors as indicated by the least squares analysis of variance calculated for the type of housing. The large herds were kept in stalls with short standing more frequently than average. Although the type of standing in itself could not be assumed to affect the diseases of the genitals, there are other significant factors of the production 
environment associated with stalls with short standing. The stalls of short standing are new, and in 10 of them a high level of productivity is aimed at through intensive silage feeding. Plentiful feeding with silage and concentrates lowers the fertility (Refsdal 1976). The high quantity of nitrogen fertilizer, which is typical to silage feeding farms, may increase the nitrate content of silage, which may according to practical observations decrease fertility (Kallela, unpublished). A high level of productivity is also frequently associated with fertility disorders (Hewett 1971). Admittedly, Hewett (1971) did not find any decrease in fertility with silage feeding, but observed that over-feeding of proteins and energy would increase infertility.

The correlation by herd ascertained herein between infertility and ketosis emphasizes the connection between infertility and productivity stress. In his detailed follow-up study Refsdal (1977) found a clear relationship between ketonaemia and the ovarial activity after calving.

Hewett (1971) emphasizes the significance upon fertility of factors associated with the intensity of milk production. According to the present study, too, it would appear that there is a greater risk that large herds with a high milk production and predominantly October-January calving will have infertility problems. Herds fed abundantly with silage should probably be referred to the same group. The high number of environmental factors, the possible intercorrelation, and the influence of the human factor in the form of oestrus control, however, make it difficult to draw exact conclusions.

\section{REFERENCES}

Anttila, J. \& K. Roine: Kliinisiä havaintoja rakkulalehmistä ja niiden hoidosta. (Clinical observations on cystic ovarian disease and its treatment in dairy cows). Suom. Eläinlääk.-L. 1972, 78, 562 572.

Bane, A.: Fertility and reproductive disorders in Swedish cattle. Brit. vet. J. 1964, 120, 431-441.

Bäckström, L., J. Mattssón, O. Wallin \& B. Vilson: Praktikjournalförsöket i Skaraborgs län 1971-1973. (Practice journal experiment in the county of Skaraborg 1971-1973). Svensk Vet.-Tidn. 1975, $27,238-250$.

Harvey, W. R.: Least squares analysis of data with unequal subclass numbers. Agric. Res. Service, US Dept. Agric. 1966, ARS 20-8.

Henricson, B.: Genetical and statistical investigations into so-called cystic ovaries in cattle. Acta agric. scand. 1956, 7, 1-93. 
Hewett, C. D.: A survey of the incidence of the repeat breeder cow in Sweden with reference to herd size, season, age and milk yield. Brit. vet. J. 1968, 124, 342-352.

Hewett, C. D.: A study of the possible effects of certain environmental factors on fertility and milk production of dairy cows in Sweden. Nord. Vet.-Med. 1971, 23, 65--85.

Kallela, K.: The incidence of plant oestrogens in Finnish pasture and fodder plants with special reference to their possible effects in cases of sterility in ruminants. Thesis, Helsinki 1964.

Kruif, A. de: Fertiliteit en subfertiliteit bij het vrouwelijk rund. (Fertility and subfertility in cattle). Thesis, Utrecht 1975.

Moberg, R.: Vorbeuge gegen die funktionellen Fortpflanzungsstörungen beim Rind. (Prevention of functional disorders of fertility in dairy cows). Fortpfl. Haust. 1965, 107, 268-272.

Pålsson, E.: Investigations into the incidence and seasonal variation in the occurrence of cystic ovarian degeneration in Swedish lowland cattle in Ystad District Cattle Breeding Society and the effect of individual bulls on its occurrence. Proc. IVth Int. Congr. Anim. Reprod., Hague 1961, 768--772.

Rasbech, N. O., P. Jochumsen \& Ib J. Christiansen: Unders $\varnothing$ gelser over sygdomsforekomst og bedriftsforhold 1. Sygdommenes klassificering, hyppighed og fordeling på malkekvægracer. (Investigations into disease incidence and farming conditions. 1. Classification, frequency and distribution of diseases within dairy cattle breeds). Kgl. Vet.- og Landbohøjsk. Inst. Sterilitetsforskn. Aarsberetn. 1967, 265-308.

Refsdal, A. O.: Fertiliteten hos kyr i relasjon til forbruk av surfor og tørt stråfor $i$ de ulike fylker i Norge. (Fertility in cows relative to the consumption of sour fodder and dry straw fodder in the various provinces of Norway). Norsk Vet-T. 1976, 88, 597-604.

Refsdal, A. O.: Ovarialfunksjon og hormonverdier ved ketonemi hos storfe. (Ovarial function and hormonal values in ketonemia of cattle). Allmänt veterinärmöte, Kompendium 1977, 160-173.

Roine, $K$. Potilaskortti praktiikkakäyttöön. (Patient register in ambulatory practice). Suom. Eläinlääk.-L. 1969, 75, $299-302$.

Roine, $K .:$ De vanligaste fertilitetsrubbningarna hos ko samt deras säsongvariationer. (The most frequent reproductive disorders and their seasonal variation in dairy cows). Nord. Vet.-Med. $1973,25,242-247$.

Roine, K.: Näkökohtia naudan steriliteetistä ja sen hoidosta. (Some aspects on sterility and its treatment in dairy cattle). Suom. Eläinlääk.-L. 1975, 81, 241-253.

Roine, $K$.: Observations on genital abnormalities in dairy cows using slaughterhouse material. Nord. Vet.-Med. 1977, 29, 188-193.

Saloniemi, H.: Some aspects of cattle health protection of Finnish dairy farms. Rep. 4th Conf. Rural Building, Sci. Soc. Build. (C.I.G.R.). Gen. Rep. 53-57. Budapest 1976.

Saloniemi, $H$. \& K. Roine: Nautakarjan sairastavuudesta ja karjakoon vaikutuksesta sairastavuuteen. (Incidence of illness in dairy 
cattle with special reference to herd size). Suom. Eläinlääk.-L. 1976, 82, 231-243.

Schjerven, L.: En klinisk unders $\varnothing$ kelse av cystiske ovarier ho ku. (A clinical study on cystic ovarian disease in dairy cattle). Thesis, Oslo 1971.

Solbu, H.: Helsekortordning 1976. (Health cards in dairy cattle 1976). Buskap og avdrått 1977, 29, 97-101.

\section{SAMMANFATTNING}

Infertilitetsfrekvensen hos ko.

Förekomsten av olika former av infertilitet har undersökts i 283 besättningar under åren 1968-1975. Besättningarnas ko-antal har årligen i medeltal varit 2.590. Följande faktorer har tagits i betraktande: variationen per år, per säsong och dess förhållande till kalvningarnas säsongvariation och sjukdomsfrekvensen samt besättningarnas storlek, ladugårdstypens och kontrollverksamhetstillhörighetens inverkan på densamma.

I materialet, som omfattade 2.304 fall av infertilitet $(0,111$ fall/ ko/år), konstaterades, att frekvensen varierade signifikant mellan år. Säsongvariationen avvek från kalvningarnas variation såtillvida, att majoriteten av fallen förekom under tiden december-april. Frekvensen av anoestrus och suboestrus $(0,015$ resp. 0,023$)$ varierade signifikant mellan år och avvek från kalvningarnas säsongvariation. Frekvensen påverkades inte av besättningens storlek, men var högre $i$ besättningar underkastade kontroll. Frekvensen av fördröjd ovulation $(0,006)$ varierade från år till år. Frekvensen av symptomfri omlöpning $(0,009)$ uppvisade ingen årsvariation. Frekvensen av äggstockscystor $(0,041)$ varierade årligen och var signifikant större under perioden december-mars. Endometrit-frekvensen $(0,014)$ syntes vara beroende av besättningen storlek och ladugårdstypen.

Såväl besättningens storlek som typen av ladugård syntes påverka infertilitetsfrekvensen, men skillnaderna visavis infertilitetstyperna var stora. Infertilitetsfrekvensen/besättning stod i signifikant korrelation till ketosfrekvensen $(r=0,15, P<0,001)$.

(Received February 4, 1978).

Reprints may be requested from: the Department of Obstetrics and Gynaecology, SF-04840 Hautjärvi, Finland. 